\title{
THIRD PARTY FUNDING FOR LITIGATION IN DISPUTE RESOLUTION MECHANISM AND ITS RECENT DEVELOPMENTS IN INTERNATIONAL COMMERCIAL ARBITRATION
}

\section{SEEMASMITI PATTJOSHI ${ }^{1} \&$ PURANJOY GHOSH ${ }^{2}$}

${ }^{1}$ Ph.D. Scholar, KIIT School of Law, Bhubaneswar, Odisha, India

\author{
${ }^{2}$ Assistant Professor, KIIT School of Law, Bhubaneswar, Odisha, India
}

\section{ABSTRACT}

The most contentious mechanism in International Commercial Arbitration is the 'Third Party Funding for Litigation' (hereinafter referred to TPFL) though, it goes around with the present practices amongst most of the developed economies of the world. The practice of TPFL has been considered as promoting a solution in the field of accessing justice particularly, for those who have been experiencing financial-constraint to pursue the international commercial arbitration proceedings. International Commercial Arbitration Proceedings being transnational are of high-valued disputes hence, ineluctably tends to be a costly episode for the parties involved. Another direct impact of the said mechanism lies in reducing both valued-time and workloads of the parties to the proceedings as well. TPFL may have the appearance to share one of the objectives of Litigation funding however, TPFL, in international arbitration proceedings facilitates financially-constraint parties to have access to speedier methods of dispute resolution in exchange for national court's intervention that are burdened with the arrears of cases in regular dispute resolution system. And again it comes to the aid of those who are financially-stressed or prioritize corporate time as highly valued one. The distinct domain of so-called Litigation Funding (e.g., Champerty or Maintenance) invokes the question of public policy hence scopes of frivolous becomes higher while TPFL, as stated above, in international arbitral proceedings is having distinct objectives, i.e., to enable financially-distressed parties to access to justice through third party before arbitral tribunals, to save valuable corporate-time, and a mode of financing. The exhaustive due diligence conducted by funders prior to entering into funding agreements would go a long way towards ensuring that only meritorious claims receive funding. The present discourse confines the review of the fundamentals of TPFL practices that ultimately contributes in delivering justice in both national and international commercial arbitration as long as it is left to self-governance.

KEYWORDS: Third Party Funding for Litigation, Doctrine of Champerty and Maintenance, Public Policy, International Commercial Arbitration.

Received: Jun 01, 2020; Accepted: Jun 20, 2020; Published: Jun 26, 2020; Paper Id.: IJMPERDJUN2020100

\section{INTRODUCTION}

International Commercial Dispute Resolution mechanism has practised such an incredible growth in the past years in Internal Commercial Arbitration that it has now become a victim of its own success. ${ }^{1}$ The distinct characteristics of 'speedy disposal', 'parties' autonomy in choice of law', 'seat of arbitration', and so on, inspired the efficacy of such alternative mode of dispute resolution mechanism. TPFL, is one such practice that has gained much vibrancy especially in International Commercial Dispute Resolution mechanism. The emerging numbers of Financers

\footnotetext{
${ }^{1}$ The Duty of Disclosure and Conflicts of Interest of TPF in Arbitration, Kluwer Arbitration blog,( accessed $8^{\text {th }}$ august 2018)
} 
(Funders) in the Litigation Markets in some developed countries of the globe, facilitating the prospective claimants in accessing to the Justice in today's fast-economy. TPFL was categorically criticized earlier and abandoned by law-makers in various legal frameworks treating it to be contrary to the Public Policy. The tortuous principles of Maintenance and Champerty ${ }^{2}$ regained its access particularly from late 2012 and early 2013 in International Commercial Dispute Resolution and some developed countries, for example, Australia, the United Kingdom and the United States, Canada, Singapore, etc. The best practices of TPFL mechanism in International Commercial Arbitration Proceedings have been recommended by the Joint Task Force constituted under the aegies of The International Council for Commercial Arbitration (ICCA) and Queen Mary University of London ${ }^{3}$ and made available for public and professional scrutiny in September 2017.

In today's fast global economy TPFL serves two primary objectives - a) an easy mode of financing; and b) saving the valuable corporate time. The chequered history of intrusion of financers in the administration of civil justice during Mercantile Capitalism, as stated above, guided the law-systems of some countries to deny the intrusion of such financers from its legal frameworks to ensure the core values of justice system and made it as elementary aspect in determining the Public Policy. Over the years the opinions of the policy-makers were relating to higher probability of defeat of fairness and fair process of law by such Financers, if allowed in the litigation markets, hence, treated such TPFL as deterrent to the administration of justice system and envisaged it to be against the public policy. Of late, the trends of trade-liberalization encouraged the convergence of the legal cultures across the nations and to attune and set a global economic order. And the recent practice of TPFL, in other words, so-called Financers in the litigation markets has been found to have been cooperating in facilitating to the provide relief to the prospective claimant to arbitral dispute, and that such funding prohibitions make little sense today.

Admittedly the agreement, to be come in into between such financer/ investor and the prospective claimant/intended litigant to the Arbitral Proceeding, is significant due to the center-stage of 'power of bargain' however, green-signaling to it with legal-restrictions may evolve out to be beneficial and contributory to fast economic growth and speedy disposal of transnational commercial disputes through International Commercial Arbitration in India as well.

India, being one of the progressive economies is perceived to have much affinity upon the Principles of Common Law system and till date encourages the nugatory approach in approving the TPFL mechanism in International Commercial Arbitration Proceeding, though Part - II of the Arbitration \& Conciliation (Amendment) Act, 2015 has been aligned with necessary modifications at par with global practices in International Commercial Arbitration with the piecemeal attention to TPFL which is now becoming the global practice. The present space in this discussion has been used to analyze the changing dimension of legal frameworks across the developed nations, especially, TPFL practice in International Commercial Arbitration Dispute Resolution mechanism and the prospective benefits as India has focused in citing it to a leading hub in global landscape of International Commercial Arbitration Dispute Resolution Centers.

Prior to formal codification of contract law recorded instances of Third Party Litigation Funding Agreements, or pactum de quota litis4 in India dated back to the 1800s, is not possible due to lack of proper records of any such litigation relating to nor any specific legislations on it in India. And again on assuming the sovereign function Independent-India

\footnotetext{
${ }^{2}$ Champerty is the process whereby one person bargains with a party to a lawsuit to obtain a share in the proceeds of the suit. Maintenance is the support or promotion of another person's suit initiated by intermeddling for personal gain. The Legal Dictionary. https://legal-dictionary.thefreedictionary.com. ${ }^{3} \mathrm{Hong}-\mathrm{Lin} \mathrm{Yu}$, Can third party funding deliver justice in International Commercial Arbitration, (2017) 20(1) Int. A.L.R. 2017.

${ }^{4}$ An agreement by which a creditor of a sum difficult to recover, promises a portion, for example, one-third, to the person who will undertake to recover it. In general, attorneys will abstain from, making such a contract, yet it is not unlawful. https://legal-

dictionary.thefreedictionary.com/pactum+de+quota+litis.
} 
installed the English legal principles and practices within the legal system, followed during the colonial era where the local practices or local laws were absent, silent and suffered from ambiguity, thus, the restrictions on Champerty and Maintenance were thought to be applicable to litigation funding as it was not an accepted legal principle in U.K. However, conflicting decisions were handed down over time, which led to uncertainty regarding enforceability of such contracts. ${ }^{5}$ The pendulum of judicial opinions in India regarding the applicability of champerty has oscillated between extreme positions. An unreported decision of Peel J in 1825 had held that the English prohibitions on champerty\& maintenance could not apply to India. ${ }^{6}$

The conflicts of Third Party Funding Litigation and Public Policy, was decided in 1876 by the Privy Council in Ram Coomar Condoo v Chandra Canto Mukerjee, ${ }^{7}$ turning judicial tide in favor of concluding that statutes of champerty and maintenance under the common law were laws particularly designed for England, to curb down the corrupt practice of judicial officers oppressing the King's subjects by maintaining vexatious suits or purchasing rights in litigation. More importantly, it was held that these laws were of a special character and the British statutes relating to them were inapplicable in India. It recognized that agreement to finance to carry on an action as consideration as the interest of the share arising out appertaining to such case would not considered to be opposed to public policy. Providing relief to impecunious litigation clearly appeared into weigh with the Privy Council, and contracts inter the nature of Litigation Funding along with a third party were treated at par with other contracts. Other decisions have also reaffirmed that the doctrines of Champerty and Maintenance should not applicable in India, and that champertous contracts cannot be declared invalid only if the object is contrary to public policy. ${ }^{8}$

Thus position since then has remained uniform, ${ }^{9}$ viz. an agreement between a disputant and Third Party to finance the total cost or partial cost of suit in consideration for a share of the profits arising out of said litigation, was not per se illegal and could not be declared void on grounds of champerty and maintenance as these doctrines were not applicable to India and that third party funding agreements do in fact provide access to justice. ${ }^{10}$ Such agreements would be tested on the anvil of equity, reasonableness, and legality of the object behind the contracts, and unconscionable terms would be hit by s 23 of the Indian Contract Act 1872. In the absence of express prohibitions on champerty and maintenance in India, objection to such contracts remained centred on public policy considerations. ${ }^{11}$

The permissibility of Third Party Litigation in India is seen in the rules of civil procedure made by various High Courts in the country which expressly recognize litigation financing and make provisions for security for costs in such cases. $^{12}$

\footnotetext{
${ }^{5}$ See, M P Jain, 'The Law of Contract Before its Codification' (1972) Journal of the Indian law Institute, Special Issue: Laws of Evidence and Contract 178

7 (1876-77) 4 IA 23,1876 SCC OnLine PC 19.

${ }^{8}$ Sri Raja VatsavayaVenkataSubhadeayyammaJagapatiBahadurGaru v Sri PoosapatiVenkatapatiRajuGaru\&Ors AIR 1924 PC 162, (1924) LW 298, 1924 SCC OnLine PC 22;

${ }^{9}$ Lala Ram Swarup v The Court of Wards (1940) 42 Bom LR 307 where the rule in Ram CoomarCoondoo was crystallised; Rattan Chand Hira Chand v Askar Nawaz Jung (Dead) by LRs \&Ors (1991) 3 SCC 67.

${ }^{10}$ KishenLalBhoomik v PeareeSoondree\&Ors 1852 SudderDewannyAdawlut (SDA) 394-397 [Case No. 137 of 1850 decided on 13 May 1852 ], where the court sought to bring clarity to the matter by holding that 'an arrangement of the nature of champerty is not of itself illegal or void' as 'it is not consistent with justice to dismiss a claim, because the claimant has some difficulty in meeting the expense of asserting that claim' by way of a third-party funding agreement. The court did however clarify that it would not enforce agreements in the nature of wagering contracts. Third-party funding agreements would not be barred due to this condition as, even the court recognised, such agreements do in fact provide access to justice.

${ }^{11}$ PannalalGendalal\&Anr v ThansinghAppaji\&Anr AIR 1952 Nag 195. Campbells (n 15) examined the position under common law jurisdic tions including India, and the decision passed by the Privy Council in the case of Ram CoomarCoondoo (n 23).

12 The Code of Civil Procedure 1908: Order XXV Rule 1 Allahabad, Andhra and Madras, Madhya Pradesh, Orissa High Court amendments; Order XXV Rule 3 Bombay, Dadra and Nagar Haveli, Goa, Daman and Diu, and Madhya Pradesh High Court amendments.
} 
The origins of TPFL have been tied back to certain practices in ancient Rome and Greece, but are most often associated with feudal practices in medieval England, when powerful noblemen lent their support to parties involved in litigation in order to advance interests of their own unrelated to the merits of the underlying claim, such as to weaken rivals or as a source of income. Such behavior promote the criminal prohibition of champerty and maintenance, same as related civil torts and doctrines of contractual nullity in the common law world.

\section{EVOLUTION, MEANING, SIGNIFICANCE OF THIRD PARTY FUNDING}

Third-Party Funding for litigation is the "mechanism or process through which parties to arbitration proceedings can finance their claims through the help of an external funder"13 or may be called investor. Third-Party funder seems to be the financier/ investor, extend financial help sought for by the claimant in order to pursue a claim, in exchange for either the interest of percentage or share of the expected reward in the final judgment.

Basically, there are two types categories has been derived. First address what is generally understood to be the "formal" form of TPFL, which involves the provision by a third party of non-recourse financing for the expenses of prosecuting the proceeding, in exchange for the pecuniary gain in any funds to be recovered by the claimant. After introducing the single claim investment (formal form of TPFL) and the manner in which it is conveyed, the paper will turn to what may be understood to be "informal" forms of TPFL, including:

- $\quad$ Respondent-side TPFL;

- TPFL in the form of litigation-related insurance products;

- "Strategic TPFL", which, as explained further below, consists of funding directed to interests other than the realization of a financial return on the claim funded; and

- Legal fee arrangements as TPFL.

Basically two categories of arrangements were in practice concerning the Third Party Funding for Litigations, firstly, extending the financial help by the financer to bear the legal expenses of the party in the proceedings in exchange for agreed portion of the award, if the claimant wins, or an ascertained amount from the respondent as arranged in the agreement; and secondly, financer negotiates to finance the single case, or portfolio of cases of a law firm in exchange for a predetermined rate of return. Thus, the financier or funder becomes a distinct legal entity from both the funded party and the law firm in both types of traditional third-party financing.

\section{"FORMAL" CLAIMANT-SIDE TPFL}

Modern TPFL naturally involves the provision of non-recourse financing to cover all or part of the costs and expenses necessary for pursuing a claim (such as legal fees, expert fees, arbitrator and administrative costs and, in some cases), in exchange for a financial interest in any favorable award that issues from the claim.

\footnotetext{
${ }^{13}$ Stavros Brekoulakis, "The Impact of Third Party Funding on Allocation for Costs and Security for Costs Applications: The ICCA-Queen Mary Task Force Report", Queen Mary University of London, (February 2016).
} 


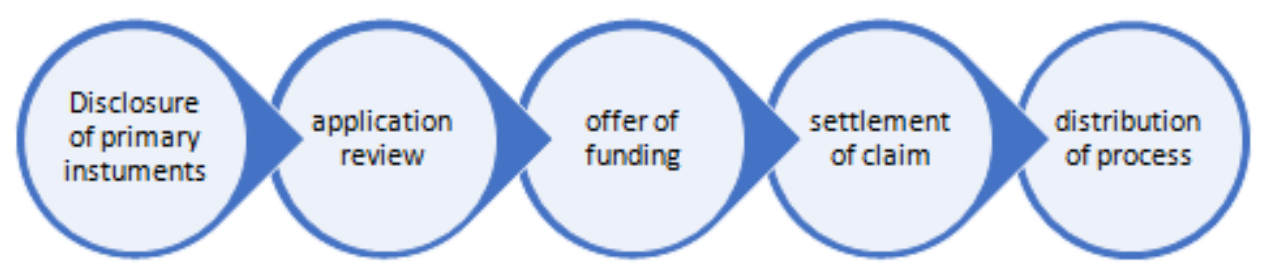

Figure 1: The Process of Applying for Funding.

The mechanism to initiate third party funding for litigation commences with first disclosure of primary important instruments in addition to provide the indicative profiles of attainable value and nature of the claim and its possible value for the appraisal of the feasibility of funding. The second stage is to review the application and any enclosed (further disclosure of) documents, required that may determine or condition predicted output of claim, costs to be incurred, and the potentiality of the party to meet the judgment. Third stage proceeds mostly relating to legal fees, disbursements, and payment of adverse costs order(s), if any, and also the security for costs if asked, by the Court or by the Arbitral Institute. Such arrangement entitles the Financier/Funder to have reimbursement the apportioned financial return as interest-fees (for accomplishment of outcomes) other than the project costs, i.e., the legal costs, practitioner costs and disbursementsand such interest success fee normally ranges between $25 \%$ and $45 \%$. Factors affecting the percentage include the size and pecuniary value of the case, and its likely duration. The fee is normally less if the case resolves sooner. The next step is a case progress which is a kind of a support to the claimant and his lawyers, it may also provide strategic planning, which is basically monitoring and management during this process. The final step is the passing of Award and Distribution of Proceeds. If the claim is successful, the defendant will be obliged to pay an agreed or determined sum of money into the plaintiff lawyer's trust account. After this sum the lawyer will deduct the fees owing to funder pursuant to the Funding Agreement, and pay the balance of amount to the client. If the claim fails, funder is responsible for paying the Defendant's costs on the terms of the funding agreement. ${ }^{14}$

\section{ENGLISH PRINCIPLES OF MAINTENANCE AND CHAMPERTY, PUBLIC POLICY\& THIRD PARTY FUNDING FOR LITIGATION}

The origins of TPFL derives from the famous common law principle of Champerty, that might be stated as "an agreement between an officious intermeddler in an exceedingly lawsuit and a litigant by which the intermeddler helps pursue the litigant's claim as consideration for receiving a part of any judgment proceeds" per se, the concept of TPFL is that the Funder would receive aapportioned amount of the prices, awardedto the claimant in the arbitration proceedings, should the claimant succeeded in its claim. The extant legal definition is "any funding provided by a natural or legal one who isn't a celebration to the dispute but who enters into an agreement with a disputing party so as to finance part or all of the value of the proceedings reciprocally for remuneration, smitten by the result of the dispute, or within the kind of a donation or grant." 15

These doctrines originate from public policy deliberations aimed to preserve the legitimate course of due process. ${ }^{16}$ They are meant to preserve the fairness of justice and still behold the basic premises for questioning the

\footnotetext{
${ }^{14}$ Conflict of interest in International Arbitration in the context of Third Party Funding, https://www.youtube.com/watch?v=fnAJB0ChJCo

${ }^{15}$ European Union's proposal for “Investment Protection and Resolution of Investment Disputes" of 12 November 2015.

${ }^{16}$ Black's Law dictionary, Seventh Edition, 1999. p. 1543.
} 
enforceability of a Litigation Funding Agreement. ${ }^{17}$ Further the US has implemented these doctrines with maintenance and champerty known as Usury and barratry mainly intended to safeguard public policy principles and due process of law. ${ }^{18}$ Barratry enhances frequency to the act of champerty for example several instances of champerty by a single person constitute barratry in some jurisdictions. However, the definition of usury varies from state to state, but generally refers to the act of "lending of money with interest "or "charging of illegal rate of interest." The applicability of usury to Third Party Funding depends on whether the state classifies this process as a loan. ${ }^{19}$

Maintenance and champerty are initially separate doctrines but sometimes they are often addressed together, ${ }^{20}$ the philosophers believes that these doctrines for the first time saw in the ancient Greek legal usages that is to revealed at the early developments of the Roman law, and reintroduced under the empire of the medieval law of West Europe, especially in England. ${ }^{21}$

Maintenance is defined as "providing of financial assistance to a holder of a claim to pursue his claim and to that the funder or provider of financial assistance holds no connection or valid interest in the claim itself." Champerty is an "aggravated" 22 form of maintenance "in which the financer or may be called funder's reason for supporting the lawsuit is that he has an interest with funded party to get a share the profits that might be gained as a result of the suit." 23 Therefore, champertyorchestrated to thatthe funder has a direct financial interest in the outcome of the claim. This definition aptly suits the case of TPFL where the funder finances the claim in exchange for apportioned amount of the damages in case the claim prevail.

\section{THIRD PARTY FUNDING IN AUSTRALIA}

Australia is known to have pioneered in configuring effective concept of Third Party Litigation Funding (further referred as TPLF) market. ${ }^{24}$ The contour of Third Party Litigation Funding principle has not had a smooth surface across the globe due to number of reasons relating to its evolution of legal rules mostly for an extant hostile legal environment for TPLF thus in hibited the early progression of TPLF in Australia, UK and many countries.

The doctrine of Maintenance and Champertywas considered as common law principles in torts and crimes in Australia at the time of colonization and subsisted coalition. In Clyne v NSW Bar Association ${ }^{25}$ the High Courtunanimously confirmed in a matrimonial litigation to strike off the wife's solicitor out of the case for questioning the making of unfounded and serious allegations made by a husband against the wife's solicitor.

\footnotetext{
${ }^{17}$ LAW COUNCIL OF AUSTRALIA, regulation of third party litigation funding in Australia: Position paper [online], June 2011, p. 7. Available at:< http://www.lawcouncil.asn.au/lawcouncil/images/LCAPDF/a-z-docs/RegulationofthirdpartylitigationfundinginAustralia.pdf.> (last consulted in 21/03/2015)

${ }^{18}$ SEBOK Anthony J., «The inauthentic claim», Vanderbilt Law Review, vol. 64, n²98, 2011, p. 4-6.

${ }^{19}$ If TPF is classifies as a loan, the court must examine if the debt's repayment is contingent or absolute if it is contingently repayable, there can be no usury. However in jurisdictions where TPF is not classified as a loan, the usury doctrine would generally not apply. See ROD AK Mariel, «It‘s about Time: A System Thinking Analysis of the Litigation Finance Industry and Its Effect on Settlement», University of Pennsylvania Law Review, vol. 155, $\mathrm{n}^{\circ} 2$, December 2006, p. 512.

${ }^{20}$ PURI Poonam, «Financing of Litigation by Third-Party Investors: A Share of Justice?», Hall Law Journal, vol.36, n³, 1998, p. 525

${ }^{21}$ RADIN Max, «Maintenance by Champerty», California Law Review, vol.24, n ${ }^{1 .}$ 1935, p. 48.

${ }^{22}$ SWAIGEN John, LEVY Alan D. and WOODS Richard E. How to Fight for What's Right: The Citizen's Guide to Public Interest Law, Ca nada, James Lorimer \&amp, 1 January, 1981, p. 63.

${ }^{23}$ ibid

24 ibid

25 (1960) 104 CLR 186
} 
The turning point in Australia emerged in the decision of the High Court of Australia inCampbells Cash and Carry Pty Limited v. Fostif Pty Limited ${ }^{26}$ when in a class action to recover the amounts, paid by retailers of tobacco products to wholesalers and representing license fees that the wholesalers did not pass onto the tax commissioner because the license fees were held to be unconstitutional.

\section{The Legal Principle related to Litigation Funding in England and Wales}

The principle of Maintenance and Champerty though were abolished as offences in the UK by the Criminal Law Act 1967 in the UK. It is not wrong to say that that both the UK and Australian laws relating to TPLF share some shared fundamentals.

In Canada, TPLF is a fairly new phenomenon. Like Australia, TPLF in Canada has carried on relatively unburdened by regulation. Canadian courts' dealing with litigation funding agreements has developed over a series of cases beginning with the decision in Dugal v Manulife Financial Corporation. In a recent case, Houle ${ }^{27}$ Bentham IMF Capital Inc. ("Bentham") become engaged via the consultant plaintiffs in a category motion proceeding, the Houles, to offer litigation funding. The Houles sought an order of the court docket approving the litigation investment agreement among the Houles, Bentham, and sophistication suggest. The investment agreement stipulated that Bentham could pay (a) all disbursements of sophistication suggest up to a maximum amount (and then class counsel would fund the disbursements), (b) any fees assessed in opposition to the Houles, (c) any protection for prices, and (d) $50 \%$ of the reasonable docketed time of class recommend as much as a prescribed most amount (after which class counsel could only be paid by way of contingency fee). The investment settlement stipulated that while the Houles and sophistication suggest had been required to hold Bentham regularly knowledgeable approximately the motion, Bentham became now not accepted to intrude with or interject itself into the lawyer-purchaser relationship among the Houles and class suggest. It also stipulated that Bentham might not be provided with statistics or documentation if such disclosure might jeopardize privilege.

\section{Third Party Funding in Eng Land and Wales}

English regulation though historically restricted the TPFL however, over the passage of time funding agreement has been gaining the ground with the growth of globalizing world and recent trends show the presence of specialist third-party funding providers inside the London market, and a few particularly focused on international arbitration, and demand calls through the Civil Justice Council and the Office of Fair Trading. However, allowing of contingency fees in a few instances have confined to traditional restrictions within the spotlight.

In Arkin v Borchard Lines, the Appeal Courtendorsed that in some cases third-party funding may increase access to justice. The court has also defined a "pure" funder would not normally be liable for costs, under fee shifting principles. In case of Arkin, somehow, the appeal court in particular preserved its discretion to conclude third-party funding arrangements as contrary to public policy, as well as to award costs against a third-party funder. Arkin doctrine is silent, ambiguous and uncertain as to whether the considerations that might make third-party funding permissible in competition claims apply or not, that is, in an investor-state arbitration, where there is an arguable public interest in enforcing treaty rights or, indeed, in an International Commercial Arbitration.

\footnotetext{
26 (2006) 229 CLR 386.

${ }^{27}$ Dugal v. Manulife Fin. Corp., 2011 ONSC 1785, P 33 (Can.).
} 
Generally Funding by lawyers/advocates in London, in their client petition, which is defined under Section 58 of the Courts and Legal Services Act 1990, now permits conditional fee arrangements, (in the case where lawyers recover nothing, if he unsuccessful in the case, but he will get up to double, if their actual fees and costs if successful) in some surroundings. Beside to that, English law still imposes mostly stringent prohibitions on contingency fee arrangements (where the lawyer receives a share of any judgment or award). In the case of Bevan Asford v Geoff Yeandle, the court held that "the prohibition on contingency fees extended to arbitrations, and dismissed earlier suggestions from given by the court". Because arbitration was a more like party autonomy and consensual process, the same public policy considerations should not apply.

\section{Third Party Funding in Hong Kong and Singapore}

As well known for the Internal Commercial Arbitration hubs Singapore and Hong Kong have established growth of arbitration by abolishing the traditional doctrines of maintenance and champerty for third party funding in arbitration. However, these jurisdictions have also introduced laws which provide for oversight of the industry. In February 2019, Hong Kong implemented legislative amendments to provide for the legality of third party funding of Hong Kong seated arbitrations. On 14 June 2017, the Hong Kong Legislative Council passed the Arbitration and Mediation Legislation (Third Party Funding) (Amendment) Ordinance 2017 (the Ordinance). The Ordinance distinguishes arbitration and mediation from traditional litigation, and permits the third party funding of arbitration and mediation in Hong Kong. The Hong Kong developments followed shortly it promotes Singapore to open up to third party funding of arbitrations seated in the jurisdiction. This reasoning was affirmed by the Singapore Court of Appeal in Otech Pakistan Pvt Ltd v. Clough Engineering Ltd holding that the doctrines of maintenance and champerty shall apply to the same degree to arbitration as it is in litigation when stating that the "purity of justice and the interests of vulnerable litigants are as important in such proceedings as they are in litigation" and adding that "the law of champerty stems from public policy considerations that apply to all types of legal disputes and claims, whether the parties have chosen to use the court process... or have resorted to a private dispute resolution system like arbitration." 28

Third Party Funding is not alien to the Indian legal market. In 2015, the Supreme Court in Bar Council of India v. AK Balaji, clarified the legal permissibility of TPF in litigation and observed that "There appears to be no restriction on third parties (non-lawyers) funding the litigation and getting repaid after the outcome of the litigation".

\section{CONCLUSIONS}

Third-party funding in International Commercial Arbitration raises a host of policy issues that are specific to this unique context. Thus, justifications for Third Party Funding that may apply in other nature of dispute may not necessarily apply in this particular area of claims. While with the growth of Third Party Funding in International Commercial Arbitration certain initiatives are exploring and addressing important issues such as conflicts of interests and security for costs, there is a series of more systemic concerns that merit further attention and analysis.

Despite being a recent growth of TPF in the liberalizing world, TPF has significantly attracted the minds and pens of scholars and legislature in only a couple of years. However, the evolution of TPF in international arbitration in various

\footnotetext{
${ }^{28}$ Maurer Anton G., “The public policy exception under New York convention: History, interpretation and application”, 2nd ed. US A, Juris Publishing, 1 June 2013, p. 166.
} 
jurisdictions worldwide has "only led to a plethora of ethical concerns and questions." Though it is difficult, to take consideration of emerging principles of TPF in ethical concerns in International Arbitration.

The popularity of TPF in the context of International Commercial Arbitration, will undoubtedly become clearer in the recent amendments and case law throughout the world. Previously, the typical of case law(varies fact to fact) and statutes/policies are focused on TPF in domestic litigation along with international commercial arbitration, which makes it clear with the abolition of the doctrine of Champerty and Maintenance, which defined a conclusive conclusions about the policies and status of TPF in international commercial arbitration. Beside all these things the lack of sufficient data, which seems to be the repeated theme in the story of Third Party Funding Mechanism, in International Commercial Arbitration and it appears that making educated guesses about the status of TPF, is what we are condemned to do until more strong data is available.

\section{BIBLIOGRAPHY}

\section{PRIMARY SOURCES}

- Arbitration \& Conciliation Act 2015

- Arbitration \& Conciliation Act 2018, Amendment

- UNICTRIAL Model Law

- 2018 Queen Mary International Arbitration Survey

- $\quad$ SIAC Model Clause

- HKIAC Model Clause

- Code of Civil Procedure Code

- Indian Contract Act, 1872

\section{SECONDARY SOURCES}

\section{Books}

- Lisa Bench Nieuwveld, Victoria Shannon Sahani, Third-Party Funding in International Arbitration, Kulwer Law International, ( $2^{\text {nd }}$ ed. 2017)

- Sahani, Victoria and Nieuwveld, Third-Party Funding in International Arbitration, Lisa Bench Nieuwveld \& Victoria Shannon, (October 1, 2012).

\section{REFERENCES}

\section{ARTICLES \& JOURNALS}

1. Jasminka Kalajdzic, Peter Cashman \& Lana Longmoor, Justice for Profit: A Comparative Analysis of Australian, Canadian and U.S. Third Party Litigation Fuding, JSTORE 2017.

2. Aren Goldsmith \& Lorenzo Melchionda, Third Party Funding in International Arbitration: Everything You Ever Wanted to Know (but Were Afraid to Ask), HEINONLINE 53 (2012). 
3. Maria Choi, Third-Party Funders in International Arbitration: A Case for Protecting Communication Made in Order to Finance Arbitration, 29 Geo. J. Legal Ethics 883 (2016)

4. Maxi Scherer, Aren Goldsmith, Third Party Funding in International Arbitration in Europe: Part 1 - Funders' Perspectives, Int'l Bus. L.J. 207 (2012)

5. Tomoko Ishikawa, Third Party Participation In Investment Treaty Arbitration, Cambridge University Press Vol. 59, No. 2 (April 2010), pp.373-412

6. Alturki, Khalid Hamad. "Corporate governance: Factors influencing voluntary disclosure by publicly traded Saudi Arabian firms." International Journal of Accounting and Financial Management Research (IJAFMR) 4.5 (2014): 15-38.

7. Thibault De Boulle, Third-Party Funding In International Commercial Arbitration, Thesis in LawGHENT UNIVERSITY, 2014

8. Hassan, R., and A. S. Bello. "The Concept of Mudarabah Investment Deposits." International Journal of Business Management and Research (IJBMR) 4.2 (2014): 63-74.

9. KshamaLoyaModani, Vyapak Desai, Asia No Longer- ' Third To Party Funding-Meets

10. Sreekala, G. "Technology's Role in Commodification of Not-For-Profit Media." International Journal of Communication and Media Studies (IJCMS) 7. 4, Oct 2017, 53-60.

11. Payel Chatterjee, Moazzam Khan and Vyapak Desai of Nishith Desai Associates, Arbitrtion Development in India, LexisNexis, 2017

12. Agarwal, Parul. "Review of Patient Satisfaction in Private Hospitals-A Study of Health Care Sector with Special Reference to Noida \& Ghaziabad." International Journal of Sales \& Marketing Management Research and Development 4.2 (2014): 27-34.

13. George R. Barker, Third-Party Litigation Funding in Australia and Europe, 8 J.L. Econ. \&Pol'y 451 (2012).

14. Tyagi, Anita. "Public Private Partnership in the Health Sector of India: Look at the Possibilities." International Journal of Economics, Commerce and Research (IJECR) 4. 4, Dec 2014, 15-24

15. C. Bogart, "Third party funding in international arbitration", Burford Capital 22 January 2013.

16. Oliver Gayner; Susanna Khouri, Singapore and Hong Kong: International Arbitration Meets Third Party Funding, 40 HEINONLINE 1033 (2017).

17. BK, Pandey, Mandoria HL, and Ashok Kumar. "A Comprehensive Study of Various Kinds of Frauds \&It's Impact." International Journal of Computer Science Engineering and Information Technology Research (IJCSEITR) ISSN (P) (2016): 2249-6831.

\section{INTERNET SOURCES}

- www.Heinonline.com

- www.Jstore. Com

- arbitrationblog.kluwerarbitration.com

- www.Manupatra.com

- www.SCC.com

- www.Legallyindia.com 
Developments in International Commercial Arbitration

- www.lexisnexisindia.wordpress.com

- www.ndtv.com

- $\quad$ https://blog.ipleaders.in

- https://barandbench.com

- $\quad$ https://ssrn.com/abstract=2349138 

